\title{
Working
}

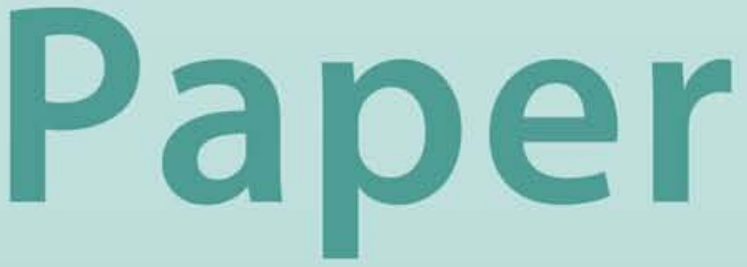


Early Ideas on Sovereign Bankruptcy Reorganization: A Survey

Kenneth Rogoff and Jeromin Zettelmeyer 


\title{
IMF Working Paper
}

Research Department

\section{Early Ideas on Sovereign Bankruptcy Reorganization: A Survey}

\author{
Prepared by Kenneth Rogoff and Jeromin Zettelmeyer ${ }^{1}$
}

March 2002

\begin{abstract}
The views expressed in this Working Paper are those of the author(s) and do not necessarily represent those of the IMF or IMF policy. Working Papers deseribe research in progress by the author(s) and are published to elicit comments and to further debate.
\end{abstract}

This paper surveys early intellectual antecedents of the Krueger (2001) proposal for creating bankruptcy rcorganization procedures at the international level. We focus on actual proposals for new procedures made from the late 1970s up to an influential lecture by Sachs (1995), with brief reference to the formal economics literature on sovereign debt. Beginning with a paper by Oechsli (1981), several key contributions are made during this period, including the analogy with domestic bankruptcy procedures, an understanding of the inefficiencies in international lending that might justify such procedures, and specific institutional and legal suggestions that continue to play a role in the current debate.

JEL Classification Numbers: B290, B300, F020, F340

Keywords: Sovereign Bankruptcy, Debt Crises, International Bankruptcy Court, Chapter 11 Author’s E-Mail Address:krogoff@imf.org, jzettelmeyer@imf.org

\footnotetext{
${ }^{1}$ We thank, without implication, Eduardo Borensztein, Andy Haldane, Thomas Laryea, Christoph Rosenberg, Rupert Thorne and Hung Tran for comments and Barry Eichengreen and Sean Hagan for pointing us to some of the references discussed in this survey. Priya Joshi provided outstanding research assistance.
} 
Contents

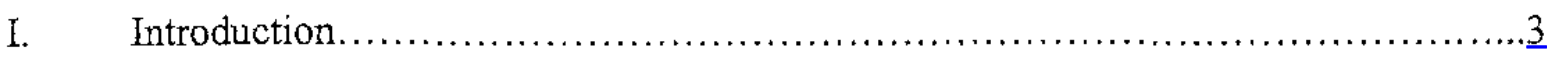

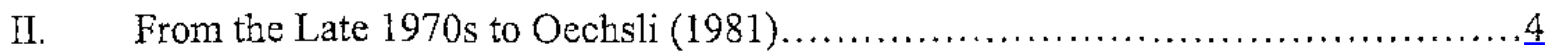

III. Debates During the Debt Crisis ............................................

IV. Proposals for a Statutory Sovereign Bankruptcy Mechanism, 1989-1994 …........

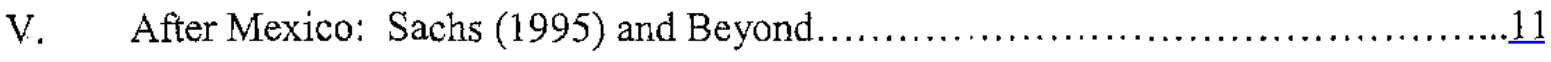

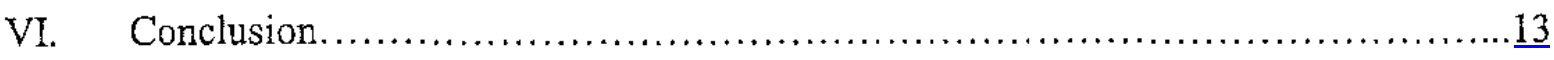

Text Box: Allied Bank International v. Banco Credito Agricola de Cartago..................

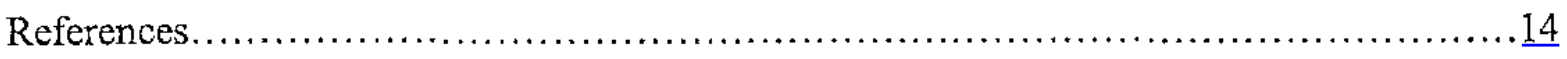




\section{INTRODUCTION}

There has been much debate recently about creating a "sovereign debt restructuring mechanism" that would apply domestic bankruptcy principles to the resolution of sovereign debt crises. ${ }^{2}$ As is widely known, this debate has a predecessor in the form of a series of papers and proposals during 1995-96, beginning with an influential speech by Jeffrey Sachs (1995) in the aftermath of the Mexican crisis. ${ }^{3}$ What is less known is that the post-Mexico debate was itself preceded by a steady stream of proposals beginning in the late 1970 s, even prior to the $1980 \mathrm{~s}$ debt crisis. While these were often more narrowly motivated than the discussions after the Mexican crisis, some were quite detailed and contained many of the elements of the proposals put forward since 1995 .

This note surveys the main ideas in the literature between the late 1970s and the well-known contribution of Sachs (1995). ${ }^{4}$ From a postwar perspective, these are "early ideas", prior to the explosion of interest in the topic following the Mexican crisis. ${ }^{5}$ Our discussion focuses on the policy debate, and touches only briefly on the formal economics literature on sovereign debt, which begins with Eaton and Gersovitz (1981) and D. Cohen and Sachs (1982). We do not mean to imply that only non-technical frameworks are appropriate for understanding international lending issues, but in the context of this note, our main interest is on the evolution of ideas on institutional and legal reform.

\footnotetext{
${ }^{2}$ See Krueger (2001). For public reactions to Krueger's proposal see Truman (2001), IIF (2001), Pettifor (2002) and EMTA (2002). Related proposals include Schwarcz (2000), Eichengreen (2000), Lerrick and Meltzer (2001) and Haldane and Kruger (2001).
}

${ }^{3}$ In addition to Sachs (1995), IMF Legal Department (1995), Hurlock (1995), Eichengreen and Portes (1995), Salter (1995), Macmillan (1995), Chun (1996) and G-10 Deputies Working Group (1996).

${ }^{4}$ We draw on a more detailed unpublished analysis in Zettelmeyer (2002), who also reviews the more recent literature.

${ }^{5}$ Between World War II and the 1970 s, with very little private lending to developing countries and no protracted debt crisis, the subject of sovereign bankruptcy generated little debate. By contrast, there were extensive discussions of the legal and economic aspects of sovereign debt crises prior to World War II (see Manes 1918, Borchard and Wynne, 1951, and Malagardis 1990 for a survey). The idea of applying bankruptcy principles to sovereigns goes back to at least Adam Smith (1776), who writes: "When it becomes necessary for a state to declare itself bankrupt, in the same manner as when it becomes necessary for an individual to do so, a fair, open and avowed bankruptcy is always the measure which is both least dishonourable to the debtor, and least hurtful to the creditor." (cited from page 883 of the 1937 edition; page $564-565$ of the 1776 edition). 
Our approach is to describe the inefficiencies which the pre-1995 literature seems concerned with, and how it proposes to resolve them. We distinguish three phases. The first precedes the 1980 s debt crisis, motivated by messy debt restructuring experiences during the $1970 \mathrm{~s}$ and the specter of a more widespread crisis. The second coincides with the $1980 \mathrm{~s}$ debt crisis. As we shall see, the debate at this time does not contribute much in terms of institutional proposals, but it greatly advances the understanding of why there is a problem in the first place. The third phasc, beginning in 1989, puts forward a series of more claborate proposals, which contain many features that are incorporated in current conceptions. Before concluding, we describe how the Sachs (1995) contribution changed the terms of the debate, and summarize the main themes that have been added by the literature after 1995 .

\section{FROM THE LATE 1970S TO OECHSLI (1981)}

Several years before the 1980 s debt crisis, rapidly growing developing country debt, protracted and difficult debt restructuring attempts in Zaire and Peru and finally the "specter of widespread defaults by LDCs" prompted calls for better creditor coordination and the development of international debt restructuring guidelines. ${ }^{6}$ The earliest reference to the desirability of a bankruptcy procedure for countries which we could find is by Ohlin (1976), who wrote that "Development finance needs something like the institution of 'honourable bankruptcy'.... It is not always recognized how important the institution of bankruptcy is to enable the credit system to work without too much risk aversion and to recover quickly from failures. The option of bankruptcy would prevent the machinery from getting clogged up by a lot of dead debt." (p. 220) Similar statements were made at fora such as the United Nations Conference on Trade and Development and the U.S. Congress, where hearings on debt servicing problems were conducted on several occasions during the late 1970 s. $^{7}$ Philipp Wellons (then at Harvard Business School) is cited as testifying before a congressional subcommittee in 1977 that

"in [developing country] default situations, some effort should be make to coordinate the activities of the public and private creditors. In an American analogy, bankruptcy,

\footnotetext{
${ }^{6}$ The quote is from Oechsli (1981), p. 318. On the Peru restructuring case, see Stallings (1979), and Cline (1981); on Zaire see Aronson (1979). Oechsli (1981) contains summaries of both cases.

${ }^{7}$ UNCTAD, "Selected Issues Relating to the Establishment of Common Norms in Future Debt Reorganizations", U.N. Document TD/AC 2/9 (1977), states that "principles for rescheduling debts should be explicit" and "creditors meeting should be convened and conducted by an international organization such as the IMF" (cited in Oechsli, 1981, p. 353). In section B of its resolution 222 (XXI) of September 27, 1980, the Trade and Development Board of UNCTAD endorsed an "operational framework" for dealing with developing country debt problems that envisages initiation by the debtor and emphasizes economic recovery, see UNCTAD (1986), p. 139.
} 
we recognize that both private and public creditors are really looking to one pot for repayment; common procedures must govern repayment from that pot. Similarly, it is very important for the entity that controls the pot in the developing country to deal with all creditors effectively and jointly." 8

The credit for the first full-fledged proposal for sovereign debt restructuring procedure, however, goes to Christopher Oechsli (1981), who explicitly invokes the Chapter 11 analogy: "Many of the procedures set forth in Chapter 11 of the Bankruptcy Reform Act of 1978 for rehabilitating financially troubled businesses can be applied profitably to renegotiation of LDC debt." (p. 354). Of these procedures, Oechsli emphasizes three: a creditor committee, an independent "examiner, a monitoring party which does not displace the debtor from control of its business". Oechsli believes the monitor could be the IMF, and stresses the need for "inclusion of the debtor in the formulation process" of a restructuring plan. He also argues that there should be a formal initiation procedure, allowing either creditors or debtors to take the initial step (although "creditors and the IMF need not accept the debtor LDC's formal petition').

In Oechsli's view, sovereign debt restructuring under the status quo suffers from several problems. Negotiations take too long, and their outcome is too uncertain, harming the debtor and delaying the rehabilitation process. Moreover, they may be insufficiently focused on "an LDC's basic development as the means to strengthen the country's credit and debt service capacity" (p. 329). According to Oechsli, these problems result from the "lack of an established procedure" and poor creditor coordination. By the latter, he seems to mean primarily a lack of coordination between classes of creditors negotiating separately-in particular, the private and official sectors-rather than across individual private creditors. In his view, this can be addressed by "an established procedural framework for debt renegotiation" that includes "all major official and commercial creditors in a comprehensive response. The procedure should avoid the long delays ... which result from separate renegotiations by different types of creditors." In particular, "the commercial creditors would not have to delay their reaction to the LDC debt problem until after the completion of the official creditor club negotiations." (p. 329)

Although he contemplates the creation of a "court-like entity" as a possibility, stating that "the IMF would seem the obvious choice for that role", Oechsli concludes that this is unnecessary. "Alternatively, creditors could specify binding arbitration procedures in their loan contracts" (including an arbitration entity along the lines of the International Center for the Settlement of Investment Disputes). "Neither, however, is necessary for Chapter 11 procedures to be applied successfully in the renegotiation context. Establishment of a renegotiation plan could continue to be by the agreement and consensus of the parties, and not by imposition from some international institution." (p. 333)

${ }^{8}$ Cited in Oechsli (1981), p. 354. 
In short, in spite of invoking the Chapter 11 analogy, Oechsli seems to implicitly attribute the inefficiencies associated with debt renegotiation to shortcomings in the official sector's approach, rather than collective action problems among private creditors. He does not discuss provisions for dealing with free riding within the private sector such as declaring a standstill, or imposing a majority-approved agreement on dissenting creditors. A Chapter 11-like procedure is important to him not as a solution of the free rider problem, but mainly because it provides a predictable timetable and clear communications channels.

This said, Oechsli's view of debt restructuring as a three way negotiation (debtor, private creditor and official creditor), and his insistence that the uncertainty about the timing and nature of the official response can complicate negotiations between debtor countries and private creditors was far sighted, and arguably borne out during the debt crisis. ${ }^{9}$ The three way negotiation framework also proved useful in understanding the potential moral hazard problem facing creditor country governments and international financial institutions, which became one of the main arguments for a sovereign bankruptcy procedure in the debate after the Mexican crisis. It was formalized by Bulow and Rogoff (1988), who first explicitly modeled the three-way bargaining between country debtors, private lenders, and creditor country governments. In their framework, knowledge that creditor country governments have a stake in the continued smooth flow of trade, and no way to credibly stay out of debt rescheduling negations, leads private creditors to charge lower risk premia to sovereigns than they might otherwise. ${ }^{10}$

\section{Debates During The DebT Crisis}

Oechsli's proposal does not seem to have become widely known. Ironically, the 1980s debt crisis itself initially had a stifling rather than inspiring effect on similar ideas, as most observers seemed too absorbed with describing and proposing solutions to the debt crisis to worry about institutional reforms. Two exceptions are the rarely cited contributions by Suratgar (1984) and Williamson (1985). Suratgar seems to be the first to suggest that an orderly approach to sovereign bankruptcy may require imposing controls on all (including private) capital flows. He proposes an "international Chapter 11 " along similar lines as Oechsli, but goes into less detail on how this should be designed. Williamson advocates a "quasi-judicial mechanism ... to try to make operational the distinction between insolvency and illiquidity" and "award debt relief in the former case while denying it in the latter", but docs not develop the Chapter 11 analogy.

${ }^{9}$ Bulow and Rogoff (1990) argue (retrospectively) that "far from speeding compromise, the presence of official creditors has tended to ossify the negotiating position of the banks and countries." (p. 35). Dooley (1994) makes a similar point.

${ }^{10}$ Related papers using a similar bargaining-theoretic approach include, among others, Wells (1993), Bhattacharya and Detragiache (1994) and Klimenko (2001). 
The most important intellectual innovation during this period was probably a much improved understanding of why there could be a problem in the first place. At the analytical level, a important milestone was Jeffrey Sachs's influential 1984 Princeton Study, "Theoretical Issues in International Borrowing". Sachs's paper, which extends his earlier theoretical work with Daniel Cohen (D. Cohen and Sachs, 1982), presents a simple, formal statement of the collective action problems associated with international debt-both pure creditor panics, and free rider problems in the context of debt rescheduling or restructuring. Citing evidence from Cline (1981) on Peru, and data on a 1983 rescheduling of loans to Brazil, Sachs argues that "even in bank syndicates significant free rider problems remain." (Sachs 1984, p. 33).

As if to prove Sachs's point, a famous court decision documented in Dell (1985), Allied Bank International $v$. Banco Credito Agricola de Cartago, illustrated the possibility both that a single creditor might "hold-out" in an international debt restructuring, and the tenuous nature of legal protections against the claims of a holdout creditor (see Box). The decision really brought home the fact that Chapter 1 I-style protections did not apply to sovereigns, as noted and lamented by Dell (1985) and many other authors writing at that time. For example, Sachs (1986a) tersely observes: "Individually, these creditors have an incentive to call in their claims against the overextended debtor countries, even if doing so injures the economic performance of the debtor so much that the creditors suffer collectively. Preventing such a destructive race to liquidate assets is one of the major purposes of a bankruptcy code, which restricts the ability of individual creditors to act against the group interest. Unfortunately, countries cannot file for Chapter 11 protection."(p. 418) ${ }^{11}$

\section{Box. Allied Bank International v. Banco Credito Agricola de Cartago}

In 1981, Costa Rica suspended debt payments to a thirty-nine member bank syndicate. A restructuring agreement was subsequently reached with all members of the syndicate but one, Fidelity Union Trust of New Jersey, which sued through an agent, Allied Bank. In April 1984, a U.S. Court of Appcals initially upheld a lower court ruling in favor of three Costa Rican banks that had acted on behalf of Costa Rica, arguing that "Costa Rica's prohibition of payments of its external debt is analogous to the reorganization of a business pursuant to chapter 11 of our Bankruptcy Code ... Costa Rica's prohibition of payment of debt was not a repudiation of the debt but rather was merely a deferral of payments while it attempted in good faith to renegotiate its obligations." Upon rehearing the case in March 1985, however, the court reversed itself after the U.S. Department of Justice submitted a brief stating that contrary to the court's initial assumptions, the U.S. government did not agree with "Costa Rica's attempted unilateral restructuring" but instead supported an IMF-guided renegotiation procedure "grounded in the understanding that while parties may agree to renegotiate conditions of payment, the underlying obligations to pay nevertheless remain valid and enforceable."

While the case was subsequently settled, the new court ruling made it clear that in the United States, Chapter 11-style protections did not apply to sovereigns: “The Costa Rican govemment's unilateral attempt to repudiate private, commercial obligations is inconsistent with the orderly resolution of international debt problems." (References: Dell, 1985, Greenwood and Mercer, 1995).

${ }^{11}$ Similar analyses can be found in Suratgar (1984), Dell (1985), UNCTAD (1986), Sachs (1986b), Raffer (1986) and Kampffmeyer (1987). See Malagardis (1990), p.181 for some additional references. 
However, the call for "Chapter 11 protection for countries" raises an important question: what would, or could, such a procedure "protect" countries from? A prerequisite to answering this question is an understanding of what makes defaults so costly from the debtor country perspective (particularly since the debtor may have means to unilaterally protect himself from creditor grab races or even debt panics, by declaring a payments moratorium). This was the focus of a key debate in the economics literature during the 1980s, beginning with an important contribution by Eaton and Gersovitz (1981), who portray a world in which sovereign borrowers are truly immune to any direct actions by creditors in the event of nonrepayment. What motivates borrowers to make any repayments is concern that they will lose their reputation in international credit markets, and thereby lose future access for an extended period. In contrast, D. Cohen and Sachs (1982) assume that if a borrower fails to make repayments, it will suffer a loss that is proportional to output. Though they do not explicitly motivate their analysis is terms of the legal rights of creditors, their framework is easier to reconcile with the view that the international legal structure governing sovereign loans matters. In the purely reputational model of Eaton and Gersovitz, the international legal system is assumed to have little or no bite on debtors anyway. Thus, introducing an international Chapter 11 would not necessarily have an impact, except perhaps to the extent that it might mitigate the reputational loss of countries who "play by the rules" when restructuring their debts. But Bulow and Rogoff (1989) show that pure reputation-based debt is not sustainable under a broad range of assumptions, unless the loss a country sustains by not repaying is much broader than just its image in credit markets. ${ }^{12}$ There remains a question as to what this loss exactly consists in, and how the introduction of a sovereign debt restructuring procedure would make a difference in this regard.

In short, although the theory literature does not provide any simple answers, it does seem to support the idea that the institutional framework governing sovereign debt workouts matters a great deal. At the same time, the problem of helping defaulting countries later regain normal access to international capital markets will present itself in even in the most smoothly functioning debt workout mechanism.

\section{Proposals for a Statutory Sovereign Bankruptcy Mechayism, 1989-1994}

The first fleshed-out plan after Oechsli (1981) appears to be Benjamin Cohen's (1989a, 1989b) proposal for a "A Global Chapter 11". Like Oechsli, Cohen envisages a structured negotiation process between debtors and creditors, the former organized in creditor committees, with monitoring by a neutral third party. Unlike Oechsli, however, he proposes the creation of a new "International Debt Restructuring Agency" (IDRA), "established by multilateral convention". 13 "Ideally, it would be organized as a wholly new and independent

\footnotetext{
${ }^{12}$ The issue of reputation is also studied by Cole and Kehoe (1996) and Wright (2001).

${ }^{13}$ Cohen initially floated his idea in the International Herald Tribune, August 13, 1987.
} 
entity in order to underscore its neutrality ... In practice, it might be more feasible to get IDRA started as a joint subsidiary of the two multilateral agencies most involved with the problem now, the IMF and the World Bank." Thus, unlike Oechsli's vision, Cohen's version of an international Chapter 11 would have a statutory basis: it would require either changes in an existing treaty, such as the IMF Articles of Agreement, or a new one.

Cohen envisages the IDRA as an administrative facilitator, mediator and monitor with more limited powers than those of a domestic bankruptcy judge. However, he leaves open the possibility that it might play a much larger role: "More controversially, IDRA could be authorized to propose its own formulas and terms for settlement ... Most controversially of all, IDRA could conceivably be authorized to compel agreement in the event of deadlock in order to suppress any remaining temptation among lenders to free ride. For example, dissenting creditors might be obliged to accept terms agreed by a qualified majority if IDRA declared the proposed settlement to "fair and equitable'." (Cohen 1989a, p. 33). Thus, Cohen's appears to be the first proposal to explicitly address the holdout creditor problem.

Also unlike Oechsli, Cohen motivates his proposal primarily in terms of a free rider problem among private creditors: "All recognize their common interest in easing the severe cash-flow strains on debtors, but none wants to pay any of the costs if they can be avoided" (Cohen 1989 a, p. 23). His approach is to deal with this is by establishing a creditor committee, requiring less than unanimous creditor support for the acceptance of a restructuring proposal, and if necessary giving the IDRA powers to impose a settlement. As far debtor incentives are concerned, Cohen suggests that debt relief granted under the process could in part be made conditional on good debtor behavior: "Creditors would be permitted to withdraw all concessions on such matters as interest rates if IDRA determined that a debtor was not complying with its policy commitments." He is less clear on how the IDRA would encourage debtors to negotiate in good faith and stick to the specified timetable. The possibility of having the IDRA authorize, and if necessary revoke, a stay of litigation while negotiations are ongoing is not discussed. Cohen seems to believe that signing an international treaty that "commits [the debtor] irrevocably to a process of conciliated negotiation" is sufficient to persuade the debtor to actually make good on these commitments.

Cohen's ideas were taken up by Williamson (1992) in a more detailed restatement of his 1985 proposal. ${ }^{14}$ Unlike Cohen, Williamson seems to suggest that a private contractual basis for the IDRA might be enough: "An International Debt Restructuring Agency would base its legitimacy on clauses in future loan contracts specifying that the terms of the contract could

${ }^{14}$ Cohen's ideas are also discussed in an extensive legal article by Miller (1991). Miller focuses on the possibility of amending the U.S. Bankruptcy Code (in particular, Chapter 9 of the code) to allow sovereigns to benefit from U.S. bankruptcy protections. However, he cautions that this may not protect debtors from claims by non-U.S. creditors, and could lead to jurisdictional problems. At the same time, he takes the view that the creation of an international debt restructuring agency as proposed by Cohen "is not a feasible alternative." 
be revised by the agency to take account of unforeseen contingencies, and that both creditors and debtors would be bound by its decision" (p. 95).

Williamson's main innovation (already hinted at in his 1985 paper) is the suggestion to condition debt relief on debtor behavior prior to the crisis, and in particularly to identify situations in which debt crises occurred through no fault of the debtor: "These criteria are intended to provide an incentive for the lenders to behave responsibly, as well as to identify circumstances in which efficiency considerations would indicate a need for debt relief." (p. 94).

Roughly coinciding with Cohen is Raffer's (1990) proposal for an international insolvency procedure modeled after Chapter 9 of the U.S. bankruptcy code, which applies bankruptcy reorganization principles to municipalities. Like Cohen, Raffer envisages a structured negotiation procedure overseen by a new international body. Raffer refers to it as a "neutral court of arbitration", implying that it would have considerable powers, much like a domestic bankruptcy court. In Raffer's plan, the IMF and World Bank-being majority-owned by creditor countries - could sit on the court as arbitrators nominated by the creditor side, while trade unions, NGOs or churches could function as arbitrators speaking on behalf of the citizens in the debtor countries. Beyond this set-up, he does not go into details, arguing that "an adaptation of Chapter 9 to the international setting would only require minor changes."

Raffer's principal innovation is the emphasis on Chapter 9 rather than Chapter 11 as the domestic analogy for sovereign bankruptcy. He seems to prefer Chapter 9 for two reasons. First, it is not vulnerable to the objection that a Chapter 11 for countries would not work because of the impossibility of "liquidating" a state entity. Furthermore, as Raffer emphasizes, Chapter 9 limits court interference with the municipalities' political or governmental powers, and gives certain groups that might be affected by the reorganization plan (such as unions and debtor employees) the right to be heard. In Raffer's view, this provides an opportunity for balancing the interests of creditors with the welfare of domestic citizens as well as national sovereignty, which he thinks were disregarded in official attempts to resolve the debt crisis during the 1980s.

A final contribution in this group is an apparently independent proposal by Reinisch (1994), the first legal scholar to advocate a supranational bankruptcy statute since Suratgar (1984). ${ }^{15}$ Like Cohen, Reinisch calls for an international bankruptcy reorganization procedure to be established by treaty and administered by a new "independent international insolvency tribunal". The debtor would take the initiative in filing for bankruptcy; creditors would be represented by committee. As in Oechsli (1981), the IMF or a similar international agency would play the role of a monitor. The free rider problem would be addressed by "mandating equal treatment" of all creditors within a creditor class and across all creditor classes except

${ }^{15}$ Reinisch is one of the few authors to cite Oechsli (1981), but does not seem to be aware of the economic literature in this area (including B. Cohen, and Raffer). 
for the IFIs. The reorganization plan would encompass not only debt reduction but also domestic economic restructuring under IMF auspices, and take into account "the domestic needs of the debtor state".

\section{AFTER MeXico: SACHS (1995) AND BEYOND}

The implementation of the Brady plan in 1991 and the subsequent resumption of capital flows to emerging markets brought a temporary lull to the literature on sovereign debt restructuring mechanisms. This was quickly reversed in the wake of the Mexican crisis and the ensuing U.S./MMF crisis loan, beginning with an influential lecture by Jeffrey Sachs (1995), "Do We Nced an International Lender of Last Resort" (April 20, 1995).

The essence of Sachs's argument is that the international financial system does indeed suffer from inefficiencies that could be used to justify a lender of last resort, but that in practice the IMF is so ineffective in exercising this function-partly by design, ${ }^{16}$ partly due to incompetence - that these inefficiencies would be addressed much more successfully if were to give up its lending role and instead assume that of a bankruptcy court. "IMF practices should be reorganized such that the IMF plays a role far more like an international bankruptcy court and far less like the lender of last resort to member governments." (p. 14)

Sachs does not go into details on how his vision of the IMF as a bankruptcy court would be implemented. He argues that the Fund's existing mandate to approve exchange rate restrictions under Article VIII (2)(b) of its charter might give it legal cover to sanction standstills, " adding that "of course, more directly, the Articles themselves could be amended." He points to the hold-out creditor problem at the beginning of his lecture, but does not state how hold-out creditors would be disciplined under his plan, and whether this would require changes in member countries' domestic laws.

Sachs's 1995 lecture does not break new ground in either the analysis of collective action problems and panics - which are amply covered in his 1984 study-or specific suggestions. The idea of using the IMF as a bankruptcy judge goes back to Oechsli (1981), and a possible role for Article VIII in sanctioning standstills had also been discussed before, including at the IMF itself. ${ }^{18}$ Sachs's lecture was nonetheless innovative in taking a much broader view of the problems which a bankruptcy mechanism might help resolve: not just the solvency crises

\footnotetext{
16 "Since the IMF lends 'taxpayer dollars' it is extremely reticent to lend in risky circumstances ... The result is that IMF loans are usually too little, too late."

${ }^{17}$ As interpreted by the courts of some Fund members, Article VIII, Section 2(b) may be invoked to stay creditor enforcement against debtors unable to service their external payments because of exchange controls that are consistent with the Fund's Articles.
}

${ }^{18}$ See IMF Legal Department (1988). 
experienced during the $1980 \mathrm{~s}$, but also a new, dangerous breed of liquidity crises a la Mexico, through a combination IMF-sanctioned standstills and "administrative priority" of new private lending. In effect, the lecture thus proposed a radical form of what much later became known as "private sector involvement" in crisis resolution. Moreover, it suggested that private sector involvement of this kind might do the job of official crisis lending much more effectively, and replace official crisis lending altogether. Furthermore, Sachs argued that this could be achieved without new treaties or institutions, merely by refocusing an existing institution, and perhaps even without changing its statutes.

No wonder, then, that the Sachs lecture had immediate and widespread resonance and a considerable impact. ${ }^{19}$ It provided the main impulse for a discussion of the topic at the G-7 Halifax summit in June of 1995, which in turn led to the G-10 paper on the resolution of sovereign liquidity crises. ${ }^{20}$ While earlier proposals did not elicit much response, virtually all the literature published after mid-1995 discusses Sachs. Although it was never formally published, Sachs's lecture probably did more to popularize the idea of international bankruptcy than all of the literature that preceded him.

Finally, we provide a brief outlook on what the literature after 1995 added to this already rich set of ideas and proposals. ${ }^{21}$ First, after the Sachs (1995) speech, the main motivation for advocating a sovereign debt restructuring mechanism begins to shift from the desire to

${ }^{19}$ See The Economist, April 22, 1995, p. 79 ("Why can't a country be like a firm?"), Financial Times, May 1 1995, p.17 ("A Role for the IMF"); Martin Wolf in Financial Times, May 15, 1995, p. 22 ("On sovereign bankruptcies"), Peter Passell in the New York Times June 22, 1995, p. 2 ("In Mexico-Style Crises, the I.M.F. could be a bankruptcy court"), Minton-Beddoes (1995), and references relating to the Halifax summit below.

${ }^{20}$ The Wall Street Journal, June 13, 1995 (p. A4) indirectly credits Sachs with putting the idea on the summit's agenda: "After considerable prodding by the U.S. and Canada, this week's economic summit will showcase a bold proposal to set up a kind of international bankruptcy court to help nations work through insolvency ... Harvard University economist Jeffrey Sachs says the IMF could get out of the loan business altogether if it moves to the bankruptcy court model." The May 1995 "Report of the [Canadian] House of Commons Standing Committee on Foreign Affairs and International Trade on the Issues of Internatnioanl Financial Institutions Reforms for the Agenda of the June 1995 G-7 Halifax Summit" explicitly recommended to the Canadian government that "Canada continue to demonstrate international leadership on debt relief issues by raising at Halifax the Sachs proposal for a larger reformed IMF role in resolving sovereign debt crises" (recommendation 16, the entire document is available at http://www.g7.utoronto.ca/g7/governmental/hc25/). See also the reporting on the summit in the Toronto Financial Post, June 23, 1995, p. 10. ("Are taxpayers on the hook for G-7's plans for reform").

${ }^{21}$ See Zettelmeyer (2002) for details and additional references. 
resolve crises more efficiently to avoiding the moral hazard associated with large official bail-outs. An international bankruptcy mechanism of some form is viewed as an alternative, less distortionary, way of dealing with the market failures that prompt large scale crisis lending in the 1990s. Second, within the spectrum between "voluntary" procedures a la Oechsli (1981) and ambitious "statutory" proposals a la B. Cohen (1989), some authors, beginning with Eichengreen and Portes (1995) and the G-10 Deputies Working Group (1996) suggest a "contractual" approach for the orderly resolution of debt crises. The idea is to deal with creditor collective action problems through private bond contracts, rather than new treaties or coordinated changes in national law. Finally, the legal and incentive issues touched on in the pre-1995 statutory proposals are developed in much more detail (see in particular IMF Legal Department (1995), Chun (1996), Schwarcz (2000) and Krueger (2001)).

\section{Conclusion}

The pre-1995 literature surveyed in this paper contributed many of the ingredients that are featured in the current debate on formal sovereign workout procedures. These include:

- the basic analogy with domestic bankruptcy procedures, beginning in the late 1970 s, and culminating in the first full-fledged framework proposed by Oechsli in 1981;

- formal economic modeling of some of the problems that arise in the market for sovereign debt. Free riding in connection with debt workouts, and the possibility of debtor panics are illustrated in Sachs (1984). The first formal model illustrating the potential moral hazard problem facing creditor country governments and international financial institutions provided by Bulow and Rogoff (1988). A literature including Eaton and Gersovitz (1981), D. Cohen and Sachs (1982) and Bulow and Rogoff (1989) debates what makes defaults costly, a critical issue to understand whether and how a sovereign bankruptcy procedure might have a positive effect.

- a series of concrete suggestions of how some of these problems could possibly be dealt with at the international level. This includes an automatic stay in payments and litigation to deal with grab races and debt panics, debtor-in-posession financing from either public or private sources (or both), majority rules that deal with the holdout creditor problem, and an international tribunal or agency that would oversee creditordebtor negotiations, mediate, exercise a monitoring function, possibly abitrate in the event of diputes (Cohen 1989, Raffer 1990, Williamson 1992) and perhaps provide a signal that might dampen the reputational costs of defaults.

Though the literature after 1995 has added a great deal, the ideas of the early contributors are sometimes lost in a whirl of "op-ed economics." We hope this short survey will be of use to those wishing to tap the rich set of ideas that were developed prior to 1995 . 


\section{REFERENCES}

Aronson, Jonathan D. (1979), "The Politics of Private Bank Lending and Debt Renegotiations," in Jonathan D. Aronson (ed.), Debt and the Less Developed Countries, Boulder, Colorado: Westview Press, pp. 283-315.

Bhattacharya, Sudipto and Enrica Detragiache (1994), "The Role of Multilateral Institutions in the Market for Sovereign Debt," Scandinavian Journal of Economics Vol. 96, No. 4: 515-29.

Borchard, Edwin M. and William H. Wynne (1951), State insolvency and foreign bondholders, New Haven : Yale University Press.

Bulow, Jeremy and Kenneth Rogoff (1988), "Multilateral Negotiations for Rescheduling Developing Country Debt: A Bargaining-Theoretic Framework," IMF Staff Papers Vol. 35, No. 4 (December): 644-57.

Bulow, Jeremy and Kenneth Rogoff (1989) "Sovereign Debt: Is to Forgive to Forget?" American Economic Review Vol. 79, No.1 (March): 43-50.

Bulow, Jeremy and Kenneth Rogoff (1990), "Cleaning Up Third World Debt without Getting Taken to the Cleaners," Journal of Economic Perspectives Vol. 4, No.I (Winter 1990): 31-42.

Chun, John H. (1996), “ 'Post-Modern' Sovereign Debt Crisis: Did Mexico Need an International Bankruptcy Forum?" Fordham Law Review, Vol 64, May: 2647.

Cline, William R. (1981), Economic Stabilization in Peru, 1975-1978, in William R. Cline and Sidney Weintraub (eds.), Economic Stabilization in Developing Countries, Washington, DC: The Brookings Institution, pp. 297-333.

Cohen, Benjamin (1989b), "A Global Chapter 11," Foreign Policy Vol. 75: 109-111.

Cohen, Benjamin J. (1989a). Developing Country Debt: A Middle Way, Princeton Essays in International Finance 173, Princeton.

Cohen, Daniel and Jeffrey Sachs (1982), "LDC Borrowing with Default Risk," National Bureau of Economic Research Working Paper No. 925, July.

Cole, Harold L. and Patrick Kehoe (1996) "Reputation Spillover Across Relationships: Reviving Reputation Models of Debt," National Bureau of Economic Research Working Paper: 5486, March.

Dell, Sidney (1985), "Crisis Management and the International Debt Problem," International Journal (Canada), Vol. 40 (Autumn): 655-88. 
Dooley, Michael P. (1994), "A Retrospective on the Debt Crisis," National Bureau of Economic Research Working Paper No. 4963, December.

Eaton, Jonathan and Mark Gersovitz (1981), "Debt with Potential Repudiation: Theoretical and Empirical Analysis," Review of Economic Studies Vol. 48, No.2 (April): 289-309.

Eichengreen, Barry (2000), "Can the Moral Hazard Caused by IMF Bailouts be Reduced?" Geneva Reports on the World Economy Special Report 1, August.

Eichengreen, Barry and Richard Portes (1995), Crisis? What Crisis? Orderly Workouts for Sovereign Debtors, London: Centre for Economic Policy Research, September.

EMTA (2002) "The IMF's Sovereign Bankruptcy Proposal and the Quest for More Orderly Sovereign Work-outs (Revised)," Remarks by EMTA Executive Director Michael M. Chamberlin at the JP Morgan Emerging Markets Winter Conference (Revised), January 29, available at http://www.emta.org/keyper/.

Greenwood, Christopher and Hugh Mercer (1995), "Considerations of International Law," Annex 3, Crisis? What Crisis? Orderly Workouts for Sovereign Debtors, London: Centre for Economic Policy Research, September 1995, pp. 103-117.

Group of Ten, "The Resolution of Sovereign Liquidity Crises. A Report to the Ministers and Governors Prepared under the Auspices of the Deputies," May 1996 (report available on the BIS Website, http://www.bis.org/publ/other.htm\#Gten)

Haldane, Andy and Mark Kruger (2001), "The Resolution of International Financial Crises: Private Finance and Public Funds," Bank of Canada Working Paper 2001-20, November 2001.

Hurlock, James (1995), “The Way Ahead for Sovereign Debt," Euromoney, August: 78-79.

IIF (2001), "Institute of International Finance Comments on Sovereign Country Bankruptcy Proposals," December 17 (available at http://www.iif.com/press/index.quagga).

International Monetary Fund, Legal Department (1988), "Legal Effects of Approval of Nonapproval of Exchange Restrictions by the Fund," EBS/88/13, January 28, 1988 (unpublished internal report to the IMF Executive Board).

International Monetary Fund, Legal Department (1995), "Note on an International Debt Adjustment Facility for Sovereign Debtors," EBS/95/90, May 26, 1995 (unpublished internal report to the IMF Executive Board).

Kampffmeyer, Thomas (1987), Towards a Solution of the Debt Crisis: Applying the Concept of Corporate Compositions with Creditors, Berlin: German Development Institute. 
Klimenko, Mikhail M. (2001), "Trader Interdependence and the Evolution of the International Financial Institutions," Role in Rescheduling Sovereign Debt, Journal of International Economics (forthcoming).

Krueger, Anne (2001), "International Financial Architecture for 2002: A New Approach to Sovereign Debt Restructuring," address given at the National Economists' Club Annual Members' Dinner, American Enterprise Institute, Washington DC, November 26 (available at http://www.imf.org/external/np/speeches/2001/sp01ind.htm)

Lerrick, Adam and Allan H. Meltzer (2001), "Blueprint for an International Lender of Last Resort," unpublished draft, October 22, 2001.

Macmillan, Rory (1995), "Towards a Sovereign Debt Work-Out System," Northwestern Journal of International Law and Business, 16 (1): 57-75.

Malagardis, Antonis N. (1990), Ein 'Konkursrecht' für Staaten? Zur Regelung von Insolvenzen souveräner Schuldner in Vergangenheit und Gegenwart, Baden-Baden: Nomos Verlag.

Manes, Alfred (1918), Staatsbankrotte. Wirtschaftliche und rechtliche Betrachtungen, Berlin: Verlag Karl Siegismund.

Miller, Brett H. (1991), Sovereign Bankruptcy: Examining the United States Bankruptcy System as a Forum for Sovereign Debtors, Law and Policy in International Business $22(1): 107-132$.

Minton-Beddoes, Zanny (1995), "Why the IMF Needs Reform," Foreign Affairs, 74: 123-33, May-June 1995.

Oechsli, Christopher G. (1981), "Procedural Guidelines for Renegotiating LDC Debts: An Analogy to Chapter 11 of the U.S. Bankruptcy Reform Act," Virginia Journal of International Law, Vol. 21, No. 2, (1981), pp. 305-341.

Ohlin, Göran (1976), "Debts, Development and Default," in Gerald K. Helleiner (ed.), $A$ World divided: the less developed countries in the international economy, Cambridge, New York : Cambridge University Press.

Pettifor, Anne (2002), "Chapter 9/11? Resolving international debt crises-the Jubilee Framework for international insolvency," January. Available from http://www.jubilee2000uk.org/.

Raffer, Kunibert (1986), "Die Verschuldung Lateinamerikas als Mechanismus des Ungleichen Tausches," Zeitschrift für Lateinamerika Wien, Vol. $31 / 31$ (1986), pp. 67-84. 
Raffer, Kunibert (1990), "Applying Chapter 9 Insolvency to International Debts: An Economically Efficient Solution with a Human Face," World Development, 18 (2): 301-311.

Reinisch, August (1994), "The Need for an International Insolvency Procedure," Österreichisches Bank-Archiv, 42 (2): 115-128.

Sachs, Jeffrey (1984), Theoretical Issues in International Borrowing, Princeton Studies in International Finance No. 54, July 1984.

Sachs, Jeffrey (1986a), "Managing the LDC Debt Crisis," Brookings Papers on Economic Activity Vol. 2, 1986.

Sachs, Jeffrey (1995), "Do We Need an International Lender of Last Resort," Frank D. Graham Lecture at Princeton University 8, April 20, 1995 (unpublished manuscript available at http://www.ksg.harvard.edu/cid/ciddirector/publicat.html\#Working).

Sachs, Jeffrey D. (1986b), Testimony to the Subcommittee on International Trade of the Committee on Finance, United States Senate, 13 May 1986, Washington: U.S. Government Printing Office: 58-90.

Salter, Leonard M. (1995), "An International Bankruptcy Code: Has the Time Arrived?" Commercial Law Bulletin, Vol. 10, May-June 1995: 21-24.

Schwarcz, Steven L. (2000), "Sovereign Debt Restructuring: A Bankruptcy Reorganization Approach," Cornell Law Review 85: 101-187.

Smith, Adam (1976), An Inquiry into the Nature and Causes of the Wealth of Nations, 1937 Edition, New York: The Modern Library.

Stallings, Barbara (1979), "Peru and the U.S. Banks: Privatization of Financial Relations," in Jonathan D. Aronson (ed.), Debt and the Less Developed Countries, Boulder, Colorado: Westview Press, pp. 225-251.

Suratgar, David (1984), "The International Financial System and the Management of the International Debt Crisis," in Suratgar (ed.), Default and Rescheduling: Corporate and Sovereign Borrowers in Difficulty," London: Euromoney Publications, pp. 151-161.

Truman, Edwin (2001), "Perspectives on External Financial Crises," Speech at New York University, December 10.

UNCTAD (1986), Trade and Development Report 1986. Report by the Secretariat of the United Nations Conference for Trade and Development, Annex to Chapter VI, pp. 138-146. 
Wells, Robin (1993) "Tolerance of Arrearages: How IMF Loan Policy Can Effect Debt Reduction," American Economic Review Vol. 83, No. 3 (June): 621-33.

Williamson, John (1985), "On the Question of Debt Relief," in Statement of the North South Round Table on Money and Finance, New York: Society for International Development, (13-14 December), p. 25-33.

Williamson, John (1992), "International Monetary Reform and the Prospects for Economic Development," in Jan Teunissen (eds.), Fragile Finance: Rethinking the International Monetary System, The Hague, FONDAD: 86-100.

Wright, Mark L.J. (2001), "Reputations and Sovereign Debt," unpublished, MIT.

Zettelmeyer (2002), "Bankruptcy Procedures for Sovereigns: A Brief History of Ideas, 1976-2001" (unpublished). 